\title{
$\nabla$ \\ A Study to Assess the Predictors of Aggression Among School Going Children
}

\section{IJCRR \\ Section: Healthcare \\ ISI Impact Factor \\ (2019-20): 1.628 \\ IC Value (2019): 90.81 \\ $\operatorname{SJIF}(2020)=7.893$}

(c) (i) (3)

Copyright@IJCRR

\section{Arati Raut ${ }^{1 *}$, Pragati Mahakulkar ${ }^{2}$, Rutusha Landge ${ }^{2}$, Gayatri Ledange ${ }^{2}$, Mayuri Lende², Bhagyashri Mahabudhe ${ }^{2}$}

'Assistant Professor, Smt. Radhikabai Meghe Memorial College of Nursing (DMIMSDU), Wardha, Maharashtra, India; ${ }^{2}$ Clinical lnstructor, Smt. Radhikabai Meghe Memorial College of Nursing (DMIMSDU), Wardha, Maharashtra, India.

\section{ABSTRACT}

Background: Aggression could be a product of our interactions with individuals in our environment which, its severity greatly differs across countries and cultures. In the recent era of childhood, aggression is the big health dilemma across the world. Aggression is a behaviour to hurt the living creatures that try to avoid the damage.

Objective: To assess the predictors of aggression among school-going children. To associate with the predictors of aggression among school-going children with the demographic variables.

Methods: A descriptive research design with non-probability convenience sampling was used. The population was 250 school going children of 5th, 6th, and 7tt in the Wardha district of Maharashtra, India.

Result: In this study, the findings show that majority of sample $93(37.2 \%)$ were from age of 12 years and $82(32.8 \%)$ of subject age of 11 years and $75(30 \%)$ subject from age of 13years. according to their residence show that average no. of sample i.e. 183 $(73.2 \%)$ were residing in an urban area. according to their Father's Education show that $71(28.4 \%)$ of the subject were from Primary Education. according to their Occupation of father show that $106(42.4 \%)$ of the subject were Farmer, overall income is between Rs $3000-5000 /$ month i.e. $48 \%$ birth Order of the subjects show that 124 (49.6\%) of the subject were from 1 st, 109 $(100 \%)$ of the subject were from Nuclear family and according to their Source of Emotional support show that $163(65.2 \%)$ of the subject were from Mother.

Conclusion: It was concluded from our study that the predictors are over protectiveness, mass media, alcoholic father, temperament, mobile addiction. We found that there was no association between selected demographic variables like age, education, residence, religion, mother's education, father's education, occupation of mother, occupation of father, the income of the family, birth order, type of family, and source of emotional support with predictors of aggression.

Key Words: Predictors, Aggression, Among, School children

\section{INTRODUCTION}

In the recent era of childhood, aggression is the big health dilemma across the world. Aggression is a behaviour that hurting the living creatures that try to avoid the damage. There are different types and function based on a variety of aggression; it has two types direct or indirect. ${ }^{1}$ The verbal and physical aggression is part of direct aggression. physical attack, tattling, repudiate and undermine is the part of indirect aggression. In verbal aggression, the children most probably use unreceptive words that make the people scared and irritated. Verbal aggression usually contains a certain outfit accompanied by physical aggression. The very strict environment, as well frequently punished by the teachers is a very important reason that the children become more aggressive. Most frequently the aggression has been diagnosed in the school-going children. ${ }^{2}$

Children and teenagers are subjected to violence in media such as television, film, music, and videogames, which poses a major risk to their wellbeing. According to comprehensive studies, media violence can lead to violent actions, desensitisation to violence, nightmares, and the fear of being harmed. Pediatricians should determine their patients' media exposure and interfere when media-related health threats occur. ${ }^{3}$

\section{Corresponding Author:}

Arati Raut, Assistant Professor, Smt. Radhikabai Meghe Memorial College of Nursing (DMIMSDU), Wardha, Maharashtra, India. Phone: 09673771592; Email: aratiraut15714@gmail.com

ISSN: 2231-2196 (Print)

Received: 05.08 .2020
ISSN: 0975-5241 (Online)

Revised: 09.10 .2020
Accepted: 14.11 .2020
Published: 20.03 .2021 


\section{MATERIALS AND METHODS}

- Research design: Descriptive research design

- Setting of the study: Saraswati Vidhya Mandiram English School Kelkarwadi, Wardha

- Population: school-going children in Saraswati Vidhya Mandiram English School Kelkarwadi, Wardha

- Sample: Children in Saraswati Vidhya Mandiram English School, Kelkarwadi, Wardha

- Sampling technique: Samples will be collected by probability sampling-Random selection.

- Sample size: Sample size for this study is 250

\section{Variables}

Research variables: predictors of aggression among schoolgoing children

\section{Inclusion and Exclusion criteria}

The school-going children were from $5^{\text {th }}$ to $7^{\text {th }}$ standard who were willing to participate in the study. Children above 13 years and below 11 years and chronically ill or mentally ill were excluded.

\section{Validity}

The validity of the tool was established in consultation with guide and experts from the field of medical surgical nursing, mental health nursing, and nursing research and statistics. The suggestion of the experts was considered and changes were made accordingly.

Plan for data analysis: data were analyzed by using descriptive inferential statistics.

Descriptive statistics: mean percentage and standard deviation of described demographic variables.

Inferential statistics: inferential statistics are like Unpaired " $\mathrm{t}$ " test and one way ANOVA was used, the analyzed data was presented in the form of tables, diagram and graphs.

\section{RESULTS}

The analysis and interpretation of data are organized under 3 section as per the objective of the study.

\section{Section I}

Distribution of school-going children according to their demographic variables

\section{Section II}

Assessment of predictors of aggression among school-going children

\section{Section III}

Association of predictors of aggression concerning demographic variables.

\section{Section I}

\section{Demography}

The demographic data of school-going children sample characteristics including age, education, residence, religion, mother's education, father's education, occupation of mother, occupation of father, the income of the family, birth order, type of family, source of emotional support.

- As regards to the age of school-going children population, it was found that majority of sample $93(37.2 \%)$ were from age of 12 years and $82(32.8 \%)$ of subject age of 11 years and $75(30 \%)$ subject from age of 13years.

- As regards to the education of school-going children, it was found that the majority of sample 93(37.2\%) were from $6^{\text {th }}$ std and $83(33.2 \%)$ of the subject were from $5^{\text {th }}$ std. and $74(29.6 \%)$ subject were from the $7^{\text {th }}$ std.

- As regard to the residence of school-going children, it was found that majority of sample $183(73.2 \%)$ were from the urban and $36(44.4 \%)$ subject were from semi-urban and $31(12.4 \%)$ of the subject were from rural.

- As regards to the religion of the school-going children, it was found that majority of sample $192(76.8 \%)$ of the subject were from Hindu and $2(0.8 \%)$ of the subject were from Christian and $6(2.4 \%)$ of the subject were from Muslim and 50 (20\%) of the subject were from others.

- As regard to mother's education of the school-going children, it was found that $136(54.4 \%)$ of the subject were from secondary education and $8(3.2 \%)$ of the subject were from Illiterate and $53(21.2 \%)$ of the subject were from primary education and $53(21.2 \%)$ of the subject were from Graduate.

- As regard to father's education of school-going children, it was found that majority of sample 113(45.2\%) of the subject were from secondary education and $11(4.4 \%)$ of the subject were from Illiterate and 71 (28.4\%) of the subject were from Primary Education and $55(22 \%)$ of the subject were from Graduate.

- As regards to the occupation of the mother of schoolgoing children, it was found that majority of sample $160(64 \%)$ of the subject were from house maker and $25(10 \%)$ of the subject were from Farmer and 54 $(21.6 \%)$ of the subject were from private service and $11(4.4 \%)$ of the subject were from Government service.

- As regards to the occupation of father of schoolgoing children, it was found that majority of sample $106(42.4 \%)$ of the subject were from private service and $47(18.8 \%)$ of the subject were from Farmer and 27 $(10.8 \%)$ of the subject were from Government service and $70(28 \%)$ of the subject were from Labor.

- As regard to the income of the family of schoolgoing children, it was found that majority of sample $120(48 \%)$ of the subject were from Rs 3000-5000/ 
month and $32(12.8 \%)$ of the subject were from < Rs3000 and 61 (24.4\%) of the subject were from Rs. $5000-10000 /$ month and $37(14.8 \%)$ of the subject were from Rs. 10000 and above.

- As regards to the birth order of school-going children, it was found that majority of sample $124(49.6 \%)$ of the subject were from 1 and $108(43.2 \%)$ of the subject were from 2 and $15(6 \%)$ of the subject were from 3 and $3(0.012 \%)$ of the subject were from 4 .

- As regards to the type of family of school-going children, it was found that majority of sample 109 $(100 \%)$ of the subject were from Nuclear family and 48 (19.2\%) of the subject were from Extended Family and $73(29.2 \%)$ of the subject were from Joint Family and $20(8 \%)$ of the subject were from single-parent Family.

- As regards to the source of emotional support of school-going children, it was found that majority of sample $163(65.2 \%)$ of the subject were from mother and $55(22 \%)$ of the subject were from Father and 19 (7.6\%) of the subject were from Peers and $13(5.2 \%)$ of the subject were from others.

Table 1: Distribution of subject with regards to their demographic variables

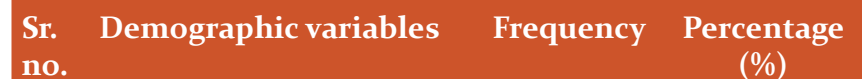

\section{$1 \quad$ Age}

11 years

12 years

13 years

Education

$5^{\text {th }}$ std.

$6^{\text {th }}$ std.

$7^{\text {th }}$ std.

3 Residence

Urban

Semi urban

Rural

4 Religion

Hindu

Christian

Muslim

Others

5

Mothers education

Illiterate

Primary education

Secondary education

Graduate
82

93

75

32.8

\section{(\%)}

37.2

30

33.2

37.2

29.6

3.2

14.4

12.4

31

76.8

o.8

2.4

20

50

3.2

21.2

$54 \cdot 4$

21.2
6 Fathers education

Illiterate 1

4.4

Primary education

28.4

Secondary education

$45 \cdot 2$

Graduate

22

7 Occupation of mother

Farmer

Private services

10

Government services

21.6

House maker

4.4

64

8 Occupation of father

$\begin{array}{lll}\text { Farmer } & 47 & 18.8\end{array}$

Private service

106

42.4

Government services

10.8

Labor

28

9 Income of family

$<$ Rs 3000

Rs 3000-5000/ month

12.8

Rs 5000-10000/ month

Rs 10000 and above

10 Birth order

1

2

3

4

32

120

48

$61 \quad 24.4$

37

14.8

$124 \quad 49.6$

$108 \quad 43.2$

$15 \quad 6$

$3 \quad 0.012$

11 Type of family

$\begin{array}{lll}\text { Nuclear } & 109 & 100\end{array}$

Extended

Joint

Single parent family

29.2

12 Source of emotional sup-

port

Father

Peers

Mother

$19 \quad 7.6$

Others

163

65.2

13

5.2

\section{Section II}

There were predictors of aggression score after the four points Likert scale was evident on test five predictors of aggression are present in the participant of the study. They are over protectiveness, alcoholic father, mass media, temperament, mobile addiction. 
Table 2: Assessment of predictors of aggression among school-going children

\begin{tabular}{|c|c|c|c|c|c|}
\hline $\begin{array}{l}\text { Sr. } \\
\text { no. }\end{array}$ & Statement & o time & 1 time & 2 time & 3 time \\
\hline & FAMILY & & & & \\
\hline 1 & $\begin{array}{l}\text { Does your parent } \\
\text { have a very busy work } \\
\text { schedule? }\end{array}$ & 16 & 114 & 64 & 56 \\
\hline 2 & $\begin{array}{l}\text { Do your parents are } \\
\text { quarrelling among } \\
\text { themselves? }\end{array}$ & 58 & 88 & 74 & 30 \\
\hline 3 & $\begin{array}{l}\text { Do your parents are } \\
\text { overprotective for } \\
\text { you? }\end{array}$ & 40 & 65 & 100 & 35 \\
\hline 4 & $\begin{array}{l}\text { Does your father take } \\
\text { alcohol? }\end{array}$ & 61 & 74 & 85 & 30 \\
\hline 5 & $\begin{array}{l}\text { Do your parents give } \\
\text { extra burden regard- } \\
\text { ing studies? }\end{array}$ & 52 & 119 & 68 & 11 \\
\hline \multirow[t]{2}{*}{6} & $\begin{array}{l}\text { Do you suffer from } \\
\text { emotional detach- } \\
\text { ment? }\end{array}$ & 54 & 117 & 56 & 23 \\
\hline & SCHOOL & & & & \\
\hline 7 & $\begin{array}{l}\text { Do you have a school } \\
\text { phobia/fear? }\end{array}$ & 113 & 99 & 20 & 18 \\
\hline 8 & $\begin{array}{l}\text { Do you scared about } \\
\text { completion of your } \\
\text { homework? }\end{array}$ & 32 & 115 & 93 & 10 \\
\hline 9 & $\begin{array}{l}\text { Do you very poor in } \\
\text { school performance? }\end{array}$ & 32 & 120 & 81 & 70 \\
\hline \multirow[t]{2}{*}{10} & $\begin{array}{l}\text { Do you have very } \\
\text { low confidence while } \\
\text { doing any school } \\
\text { activities? }\end{array}$ & 54 & 100 & 80 & 16 \\
\hline & SOCIAL AND MASS N & IEDIA & & & \\
\hline 11 & $\begin{array}{l}\text { Do you watch } \\
\text { violence videos on } \\
\text { computer/ TV? }\end{array}$ & 16 & 66 & 134 & 34 \\
\hline 12 & $\begin{array}{l}\text { Do you trouble to } \\
\text { control temper while } \\
\text { you teasing by some- } \\
\text { one? }\end{array}$ & 17 & 97 & 101 & 35 \\
\hline 13 & Do you use mobile? & 13 & 38 & 103 & 96 \\
\hline 14 & $\begin{array}{l}\text { Do you recently ex- } \\
\text { posed to a traumatic } \\
\text { event? }\end{array}$ & 45 & 106 & 73 & 26 \\
\hline 15 & $\begin{array}{l}\text { Do you afraid to } \\
\text { mingling with friends } \\
\text { / society? }\end{array}$ & 17 & 105 & 88 & 40 \\
\hline
\end{tabular}

\section{Section III}

Association of predictors of aggression score about demographic variables

There is no significant association between age, education, residence, religion, mother's education, father's education, occupation of mother, occupation of father, the income of the family, birth order, type of family and source of emotional support of the study participant.

\section{DISCUSSION}

The present study illustrated predictors of aggression among school-going children in which predictors of aggression score after the four-point Likert scale was evident on test five predictors, They are over protectiveness, alcoholic father, mass media, temperament, mobile addiction. And there is no significant association between age, education, residence, religion, mother's education, father's education, occupation of mother, occupation of father, the income of the family, birth order, type of family and source of emotional support of the study participant. ${ }^{4}$

The present study conducted by David Moreno Ruiz to examined the influence of family and classroom environments on the development of particular individual characteristics, including the level of empathy, attitude to institutional authority and perceived social reputation, and the role these characteristics may, in turn, play in school aggression. Participants wear 1319 adolescents aged 11-16 (47\%Male) Drawn from state secondary school in Valencia (Spain). In the previous studies suggest that these variables may contribute to aggressive behaviour depending on adolescent's gender, two different meditational structural models wear calculated, respectively, for boys and girls. ${ }^{5}$

Results show that positive family environment has a stronger protective factor for girls in the development of problems of behaviour at school, like aggression, misbehaviour whereas for the boys the positive school environment is the helping with developmental problems. The present study was done by Mihai MARIAN to Predictors of aggression for children: institutionalization or family that research focuses on the differences in attributional style, aggression and decision making about the personal future, between institutionalized children and those who live with their families. The study shows that aggressive behaviours directly related to the Poverty, uncertainty, the lack of a cultural model, the absence of family experiences or the lack of connection with a family it may interrupt in the overall development of the children. A sample of 183 children from the $4^{\text {th }}$ and $5^{\text {th }}$ grade was used (from public school within the vest area of Romania). The result shows that family background and psychological factors may influence their behaviour. ${ }^{6}$

Aggression to typically is diagnosed in school-going children. In the case of early diagnosis, there are different forms of aggressive behaviour in school-going children. Such as discontent in social interaction with peer poor interpersonal relationship, low self-confidence. ${ }^{7}$ 
The prevention of the children from the aggression is one of the more complicated problems facing by the parents. ${ }^{8}$ Despite the fact that peer context has a major effect on the development of adolescent aggression, few studies of relational aggression have explicitly defined and assessed peer groups, restricting our ability to draw systematic conclusions about the degree and significance of peer control. The current research used a developmental paradigm to look at the effect of peer groups on individual levels of physical and relational violence in 6th and 7 th grade students $(n=346,51$ percent female) over the course of a year. The researchers used a multilevel network approach in which peer groups were defined using social network analysis and peer group impact was assessed using hierarchical linear modelling (HLM). After correcting for other peer group traits as well as other individual risk and protective factors, HLM analyses showed that peer group aggression (physical and relational) at time 1 was predictive of individual aggression levels at time. Physical aggression tends to be less endemic to peer networks, and is more likely to occur in smaller, mostly male networks, despite the fact that both types of aggression were observed in peer networks. ${ }^{9}$ The current study highlights the importance of understanding the influence of peer group membership on adolescent aggression and points to important implications for prevention.

\section{CONCLUSION}

It was concluded from our study that the predictors are over protectiveness, mass media, alcoholic father, temperament, mobile addiction. We found that there was no association between selected demographic variables like age, education, residence, religion, mother's education, father's education, occupation of mother, occupation of father, the income of the family, birth order, type of family, and source of emotional support with predictors of aggression.

\section{Conflict of interest: Nil}

\section{Acknowledgement: Nil}

Funding: Self-funding

\section{REFERENCES}

1. Liu J, Lewis G, Evans L. Understanding Aggressive Behavior Across the Life Span. J Psychiatr Ment Health Nurs 2013 Mar;20(2):156-68.

2. Lan KL, Abdullah MC, Roslan S. Understanding media violence and the development of aggressive behaviour of school children. Procedia - Soc Behav Sci 2010;7:522-527.

3. The Media and Aggression: From TV to the Internet. Ed Donnerstein. Available from: http://www.sydneysymposium.unsw. edu.au/2010/chapters/DonnersteinSSSP2010.pdf.

4. Ravindran OS, Hima K, Natarajan S, Sathianathan R. Behavioral problems and temperamental characteristics among children in alcoholic families. J Mental Health Hum Behav 2018;23:5256.

5. López EE, Pérez SM, Ochoa GM, Ruiz DM. Adolescent aggression: Effects of gender and family and school environments. J Adolescence 2008;31(4): 33-450.

6. Marian M, Roseanu G, Mocan D. Predictors of aggression for children: institutionalization or family? In book: Studies on literature, discourse and multicultural dialogue (pp.126-135)Publisher: Arhipelag XXIEditors: I. Boldea. 2013:126-135.

7. Bandura A. Self-efficacy mechanism in human agency. Am Psychol 1982;37(2):122-147.

8. Werner NE, Crick NR. Maladaptive Peer Relationships and the Development of Relational and Physical Aggression During Middle Childhood. Soc Dev 2004;13(4):495-514.

9. Low S, Polanin JR, Espelage DL. The Role of Social Networks in Physical and Relational Aggression Among Young Adolescents. J Youth Adolesc 2013;42(7):1078-1089. 